\section{PENGARUH MOTIVASI DAN LINGKUNGAN KERJA TERHADAP KEPUASAN KERJA GURU DI SEKOLAH ADVENT AIR BERSIH MEDAN SAAT PANDEMI COVID-19}

\author{
Gabriella Ginting', Valentine Siagian² \\ Fakultas Ekonomi Universitas Advent Indonesia, Bandung ${ }^{1,2}$ \\ 1831011@unai.edu ${ }^{1}$; valentine@unai.edu $^{2}$
}

\title{
ABSTRAK
}

\begin{abstract}
Penelitian ini bertujuan untuk mengetahui pengaruh motivasi dan lingkungan kerja terhadap kepuasan kerja selama masa pandemi Covid-19. Kami menggunakan data primer dengan mengumpulkan data melalui kuesioner yang disebarkan kepada guru-guru di Sekolah Advent Air Bersih Medan. Kami menggunakan metode kualitatif dan data yang terkumpul diolah dengan SPSS 25. Hasil penelitian menunjukkan bahwa secara parsial, motivasi berpengaruh positif dan signifikan terhadap kepuasan kerja dan lingkungan kerja berpengaruh positif namun tidak signifikan terhadap kepuasan kerja . Secara simultan motivasi dan lingkungan kerja berpengaruh positif dan signifikan terhadap kepuasan kerja. Secara empiris hal ini menunjukkan bahwa sebagai guru lingkungan kerja merupakan tempat yang nyaman untuk berbagi ilmu secara langsung kepada siswa, sementara situasi pandemi COVID-19 telah mengambil hak istimewa yang tidak dapat digantikan oleh kelas online namun para guru berusaha semaksimal mungkin untuk mengatasinya. situasi.
\end{abstract}

Kata Kunci : Motivasi, Lingkungan Kerja , Kepuasan Kerja

\begin{abstract}
This study aims to determine the effect of motivation and work environment on job satisfaction during the Covid-19 pandemic. We used primary data by collecting data through questionnaires distributed to teachers at Air Bersih Adventist School, Medan. We used qualitative method and the data collected was processed with SPSS 25. The result shows that partially, motivation has a positive and significant effect on job satisfaction and work environment has a positive but not significant effect on job satisfaction. Simultaneously, motivation and work environment have a positive and significant effect on job satisfaction. Empirically this shows that as a teacher the work environment is a comfortable place to share the knowledge directly to the students, while the COVID-19 pandemic situation has taken that priviledge that cannot be replaced by online class and yet the teachers tried their best to overcome the situation.
\end{abstract}

Keywords: Motivation, Work Environment, Job Satisfaction

Diterima: 1O September 2021; Direvisi: 29 September 2021; Diterbitkan: Oktober 2021

\section{PENDAHULUAN}

Berbicara mengenai pendidikan, sekolah adalah tempat yang tepat untuk mendapatkan pendidikan tersebut. Sekolah Advent Air Bersih Medan adalah salah satu sekolah swasta yang dapat bersaing dengan sekolah yang lainnya. Sekolah Advent Air Bersih memiliki tujuan untuk membangun dan mengembangkan siswa dan siswi dalam hal akademis, sosial dan spiritual. Dari 
tujuan tersebut Sekolah Advent Air Bersih berjanji untuk memberikan pendidikan yang seimbang untuk setiap anak didik yang ada di sekolah.

Pendidikan adalah aktivitas yang dimana tenaga pengajar atau seorang pendidik melakukan pengajaran dan mereka akan disebut tenaga kependidikan yang bermutu seperti guru, dosen, tutor, ataupun istilah yang lain (Iskandar, 2014). Seorang pendidik yang bermutu seperti guru mampu melibatkan para siswa/siswi untuk mengali dan mengembangkan kemampuan yang dimiliki siswa/siswi. Dalam kegiatan untuk mencapai suatu tujuan pendidikan maka akan melibatkan perangkat pendidikan seperti materi pembelajaran, media dan sumber belajar yang ada sehingga proses pembelajaran yang akan mengembangkan potensi siswa/siswi sendiri.

Pendidikan merupakan fasilitas untuk ditingkatkan mutu kesejahteraan warga yang pada akhirnya bisa membawakan bangsa dalam mencapai kemakmuran (Hermansyah, 2020). Pada keberadaan dari tenaga pengajar/guru diminta untuk dapat memberikan perubahan yang baik dalam proses pembelajaran. Pemahaman dari seluruh lapisan yang menyatakan kompetensi seseorang guru dibutuhkan buat menciptakan mutu pembelajaran yang lebih bermakna (Musanna, 2012)

Sejak awal 2020 dunia sedang dihadapkan pada masa-masa yang sulit, yaitu akibat dari pandemi Covid-19. Sehingga saat ini berpengaruh pada dunia pendidikan, dimana semua siswa/siswi diwajibkan untuk melakukan pembelajaran jarak jauh. Saat pandemi Covid-19 banyak kalangan merasa tidak mampu menghadapinya, jadi banyak diantaranya siswa/siswi merasakan adanya dampak negatif. Dampak negatif yang dirasakan oleh para tenaga pelajar yaitu bagaimana pembelajaran yang mereka dapatkan belum semuanya diberikan secara maksimal, seperti banyaknya siswa/siswi yang tidak memiliki akses yang memadai dalam pembelajaran jarak jauh yang sedang berlangsung.

Dalam hal ini, surat edaran yang disampaikan Kementerian Pendidikan dan Kebudayaan Republik Indonesia (Kemendikbud) bahwa adanya Surat Edaran Nomor 15 Tahun 2020 menyampaikan bahwa penyelenggaraan pembelajaran dilakukan dari rumah pada masa Covid-19. Dalam surat edaran yang diberikan Kemendikbud dapat dipastikan bahwa tenaga pengajar mampu memberikan pengajaran kepada peserta didik untuk mendapatkan pembelajaran secara baik, melindungi para peserta didik dari dampak buruknya Covid-19 dan memberhentikan penyebaran penularan Covid-19 dan tetap memastikan dukungan baik melalui psikososial untuk peserta didik dan orang tua. Dari penjelasan tersebut dapat disimpulkan bahwa proses pembelajaran akan dilakukan secara daring atau tidak dengan tatap muka pada semester yang baru (Kemendikbud, 2020).

Guru adalah tenaga pengajar yang memastikan sistem pendidikan berjalan dengan baik dan seorang guru wajib menunjukkan kepedulian kepada anak didiknya. Guru sering terpaut dengan komponen manapun dalam sistem pembelajaran, seperti yang diselenggarakan di sekolah. Saat ini guru sedang dituntut untuk melaksanakan kegiatan belajar secara daring/online, yaitu dimana guru melakukan pembelajaran secara jarak jauh atau tidak melakukan secara tatap muka dengan siswa/siswi. Untuk saat ini guru juga diberikan tuntutan 
tambahan untuk memastikan tercapainya tujuan pendidikan akademik maupun non akademik. Guru juga memiliki kewajiban dalam menentukan keselamatan siswa/siswi secara raga dan psikis. Dalam teori yang disampaikan (Darmawan, 2016) kemampuan totalitas para guru dapat ditingkatkan melalui pengembangan motivasi kerja. Motivasi kerja guru akan meningkat jika hasil kerja mereka dapat dipercaya, memperoleh pengakuan dari kerjanya, mereka merasakan keadilan di lingkungan kerja dan mendapat tantangan untuk menunjukkan kemampua mereka. Dengan seluruh kemampuan yang guru berikan kepada siswa/siswi baik dalam pembelajaran dan kualitas pengajar yang diberikan guru dapat memberikan kepuasan sendiri dalam hal pengajaran yang dilakukan guru untuk para siswa (Toropova, 2021).

(Firmansyah, 2008) menyampaikan bagaimana agar tujuan individu dan tujuan organisasi membuat keduanya tercapai, maka perlu berbagai cara dilakukan untuk menghasilkan nilai tambah yang dapat memotivasi guru dan karyawan untuk lebih giat dalam bekerja, diharapkan dalam mewujudkan tujuan guru dan karyawan dengan memprioritaskan tujuan organisasi terlebih dahulu. Dari pernyataan diatas dapat dilihat bagaimana tujuan tersebut menuntut agar diterapkan dalam diri guru maupun karyawan yang berada di sekitar sekolah, untuk membuat para pelajar merasa aman dan mengerti bahwa tujuan tersebut baik adanya.

Motivasi merupakan proses psikologis dasar. Aspek motivasi menampilkan daya saing dalam organisasi secra natural bersama dengan anggapan, karakter, perilaku, serta pendidikan, motivasi ialah elemen berguna dari sikap (Seniwoliba, 2013). Dengan adanya rasa ingin menunjukkan hasil yang terbaik guru harus memiliki motivasi yang terbaik dalam hal mengajar dan untuk mendapat kualitas pengajaran yang baik dengan adanya dorongan yang kuat dalam melaksanakan tugasnya sebagai seorang tenaga pengajar (Amin, 2015). Untuk adanya dorongan motivasi yang tercipta maka lingkungan sekolah merupakan hal yang tepat untuk terciptanya motivasi dari tenaga pengajar. Dengan adanya penghargaan yang diberikan juga merupakan motivasi bagi guru dalam melaksanakan tugasnya.

Dalam hal mendapatkan motivasi dalam diri seorang guru maka dapat diketahui bahwa peran dari lingkungan pekerjaan mereka adalah salah satu dampak positif atau negatif pada motivasi pada guru dan juga karyawan. Dimana lingkungan kerja merupakan segala hal yang berada di sekitar para guru dan karyawan dalam mempengaruhi diri dalam mengerjakan pekerjaan yang diberikan.

Dengan begitu lingkungan kerja yang baik dan memberikan kenyamanan bagi guru, karena guru merupakan tenaga pengajar yang langsung bertatap muka dengan siswa dan memberikan efek positif kepada siswa. Dengan begitu guru harus mendapatkan kenyamanan pada saat melakukan kegitan belajar mengajar, sehingga dapat berkonsentrasi dalam membagikan dan menyampaikan pengetahuan kepada siswa. Pada pernyataan diatas bisa dilihat dalam teori yang disampaikan Nitisemito (2011) dan Sari (2013) mengatkan lingkungan kerja adalah segala sesuatu pada sekitar para pekerja akan dapat memberikan pengaruh terhadap dirinya dalam melaksanakan tugas-tugas yang diberikan.

Menurut Harahap (2019) menyampaikan bahwa kepuasan kerja merupakan tanggapan seorang pekerja 
tentang bagaimana mereka melakukan segala sesuatu yang baik dan dipandang dari bagaimana hasil akhir dari pekerjaan yang mereka lakukan. Kepuasan kerja merupakan suatu hal yang juga harus diperhatikan dari bagaimana mereka melakukan tanggung jawab terhadap pengajaran yang diberikan dan dapat memberikan hasil yang terbaik kepada para siswa dan untuk menghasilkan tujuan yang maksimal dalam sekolah (Rasyid, 2020).

Dari penjelasan yang disamapaikan diatas dapat dilihat bagaimana kondisi dan kendala yang dirasakan oleh para guru untuk dapat melakukan pembelajar pada saat pandemi covid-19 sangatlah tidak mudah. Guru banyak dituntut untuk lebih aktif untuk dapat memberikan pengajaran yang dapat dimudah oleh para siswa, karena tidak sedikit para siswa merasa bahwa apa yang mereka dapatkan pada saat belajar secara daring tidaklah maksimal.

Permasalahan yang terjadi ini sesuai dengan penelitian yang di teliti oleh Afia \& Anwar (2013) juga mengungkapkan adanya pengaruh yang positif dan signifikan untuk menghasilakan kepuasan kerja di Unit SMP Yayasan Pendidikan Dharma Putra. Dalam pembahasan diatas menunjukkan bahwa kepuasan kerja berpengaruh positif dan sifnifikan, dengan adanya penelitian terdahulu maka untuk atasan dan juga tenaga pengajar/guru yang adanya disekitarnya dapat memberikan dampak untuk meningkatkan kepuasan kerja yang dimiliki setiap individunya. Rosowulan (2018) juga menjelaskan bagaimana pengaruh lingkungan kerja secara positif dan signifikan terhadap kepuasan kerja terhadap guru honorer di SMK Negeri di Kota Bekasi, dimana lingkungan kerja merupakan tempat yang dimana dapat menyelesaika pekerjaan, dangan melihat lingkungan kerja yang nyaman dan tenang. (Hamdi, 2021) bagaimana kepuasan kerja tidak berbeda secara signifikan terhadap kepuasan yang dimiliki oleh guru baik pada jenis kelamin, masa kerja dan status sertifikasi. Dari penyampaian hasil terdahulu diatas dapat dengan mudah membantu dan mendukung peneliti dalam melakukan penelitian Pengaruh Motivasi dan Lingkungan Kerja Terhadap Kepuasan Kerja Guru di Sekolah Advent Air Bersih Medan saat Pandemi Covid-19.

Adanya tujuan yang dilakukan oleh peneliti untuk mengetahui pengaruh motivasi dan lingkungan kerja terhadap kepuasan kerja guru di sekolah Advent Air Bersih Medan saat Pandemi Covid19.

\section{LANDASAN TEORI}

\section{Motivasi}

Menurut Simamora (2006) dan Dufruddin (2019) motivasi adalah dorongan intelektual untuk menuntun dan mendorong untuk mencapai tujuan. Motivasi merupakan suatu keadaan yang mendorong dan menggerakkan dalam diri seseorang untuk menunjukkan kemampuan dan keterampilan yang mereka miliki untuk melakukan suatu aktivitas dengan mendapatkan hasil kerja yang maksimal dan mencapai tujuan suatu organisasi. Motivasi adalah rangkaian yang disimpulakn dari proses yang dapat mempengaruhi dan mengarahkan perilaku pekerja untuk mencapai sesuatu tujuan yang spesifik (Danish, 2010). Motivasi guru merupakan suatu energi kekuatan atau keinginan untuk membuat guru melakukan tindakan tertentu. Dari hal ini dapat menuntun guru dalam hal melakukan hal tertentu dan juga mennjauhkan diri dar melakukan hal tertentu (Kalyar, 2018) 
Motivasi merupakan dorongan yang seorang individu miliki untuk lebih mengetahui, mengerti dan percaya akan kemampuan yang mereka miliki (Filgona, 2020). Dimana individu tersebut mengetahui sampai mana tujuan yang mereka capai dari apa yang mereka kerjakan. Dari uraian diatas dapat disimpulkan bahwa motivasi merupakan hal yang sangat penting dalam kehidupan, karena dimana dalam mengerjakan segala sesuatu motivasi merupakan dorongan yang terpenting untuk menyelesaikan masalah atau keadaan yang harus diselesaikan. Jika orang bekerja dalam organisasi yang dikelola dengan baik akan mempunyai motivasi dan kepuasan lebih tinggi (Hartoyo Darmawan et al., 2019) (Hardiansyah et al., 2019).

Indikator yang ada pada motivasi menurut (Novyanti, 2015) yaitu, motivasi untuk 1). Berprestasi. 2). Motivasi untuk berkuasan 3). Motivasi untuk berafiliasi.

\section{Lingkunga Kerja}

Lingkungan kerja adalah suatu tempat pekerjaan yang dimana lingkungannya berisi para individu yang bekerja. Dimana di dalamnya terdapat interaksi diantara individu. Lingkungan kerja termasuk didalam lingkungan kerja internal dan lingkungan kerja eksternal yang dimana dapat mempengaruhi individu yang bekerja melakukan tugas pekerjaan dengan tujuan (Gunaseelan, 2012). Yumaroh (2017) mangatakan lingkungan kerja adalah suatu keadaan yang dimana suasananya sangat berpengaruh terhadap kinerja guru, baik secara nyata dan tidak nyata.

Menurut Kristanti (2017) lingkungan kerja membentuk suatu hubungan disekitar tenaga pengajar dan karyawan dalam melaksanakan kewajibannya. Selanjutnya Ruscahyono
(2014) menyampaikan bahwa keadaan pada lingkungan kerja sangat berpengaruh untuk kepuasan kerja, dimana akan meningkatkan kinerja yang dimiliki seseorang dalam lingkungan kerja dan dapat menyelesaikan segala tugas-tugas dan tanggung jawab yang diberikan. Dari uraian diatas dapat disimpulkan bahwa lingkungan kerja sangatlah penting untuk para guru maupun karyawan dalam melakukan tugas-tugasnya. Karena mereka merasa nyaman berada di lingkungan kerja yang positif maka pekerjaan dan tugas-tugas mereka dapat terselesaikan dengan baik.

Kemudian indikator dari lingkungan kerja menurut (Novyanti, 2015) yaitu adanya 1). Kondisi kerja. 2). Fasilitas kerja. 3). Peraturan kerja.

\section{Kepuasan Kerja}

Wibowo (2014) menyampaikan kepuasan kerja merupakan sebagai suatu tanggapan emosional terhadap suasana kerja. Dimana tiap orang mempunyai tingkat kepuasan kerja yang berbeda, sehingga dalam pencapain kepuasan kerja, para individu dituntut buat sanggup berhubungan dengan rekan kerja, pimpinan dan mematuhi peraturan yang berlaku didalamnya. Menurut Abdulah (2020) kepuasan kerja adalah suatu perasaan atau emosi yang diperlihatkan oleh seorang pekerja dalam pekerjaan mereka. Selanjutnya Amir (2014) menyampaikan bahwa kepuasan kerja guru dapat dilihat dari bagaimana seorang tenaga pengajar dalam terselesaikan tugas-tugas yang dimana menjadi tanggung jawab tenaga pengajar secara tepat waktu, dan saat itu juga guru dapat merasakan kerajinan, ketekunan dan memiliki kreativitas dalam bekerja.

Dari penjelasan diatas dapat ditarik kesimpulan bahwa kepuasan kerja merupakan keadaan atau suasana 
dan emosi dalam diri individu dalam melaksanakan pekerjaannya, dimana emosi dibentuk untuk dapat melakukan pekerjaan mereka dengan menunjukkan hasil yang maksimal.

Kepuasan kerja diukur dengan indikator yaitu: 1). Kerja itu sendiri 2). Tanggung jawab.

\section{Kerangka Penelitian}

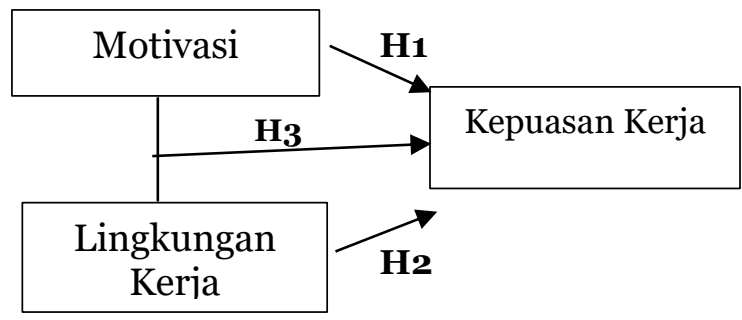

Hipotesis :

H1: Pengaruh Motivasi terhadap Kepuasan Kerja

H2: Pengaruh Lingkungan Kerja terhadap Kepuasan Kerja

H3: Pengaruh Motivasi dan Lingkungan Kerja terhadap Kepuasan Kerja

\section{METODE PENELITIAN}

Penelitian ini di lakukan di Sekolah Advent Air Bersih yang berlokasi di Jalan Air Bersih No.98A, Sudirejo l, Kec. Medan Kota, Kota Medan, Sumatera Utara-Indonesia. Dalam penelitian ini, menentukan populasinya adalah semua guru yang ada di Sekolah Advent Air Bersih Medan dengan jumlah guru seluruhnya 30 orang.

Peneliti mengumpulkan data dengan cara menyebarkan kuesioner pada seluruh guru yang ada di Sekolah Advent Air Bersih Medan, semua guru bersedia untuk mengisi kuesioner yang diberikan. Kuesioner di sebar dimulai pada bulan Desember 2020 hingga bulan Februari 2021 peneliti mendapat data kuesioner. Pembagian kuesioner yang dilakukan peneliti menggunakan google form. Kuesioner yang dibuat menggunakan skala likert yang terdiri : (1) Sangat tidak setuju , (2) tidak setuju, (3) netral, (4) setuju , (5) sangat setuju.

Dalam penilitian ini peneliti menggunakan Uji Validitas, Uji Realibilitas, Uji Koefisien Determinasi, Uji Regresi Berganda, Uji Parsial dan Uji ANOVA. Peneliti menggunakan software SPSS untuk mengolah data responden yang didapat dari kuesioner

\section{HASIL PENELITIAN DAN PEMBAHASAN \\ Uji Validitas}

Dari hasil uji validitas diperoleh hasil bahwa pernyataan yang digunakan pada variabel motivasi item 4 dan 11 memiliki nilai $\mathrm{r}$ hitung $<\mathrm{r}$ tabel $(0,361)$. Dengan hasil tersebut maka item 4 dan 11 dihapus dari instrumen variabel motivasi sehingga total pernyataan yang digunakan dalam variabel motivasi menjadi dua belas. Untuk variabel lingkungan kerja, diperoleh bahwa item 4 dan 5 memiliki nilai $r$ hitung $<\mathrm{r}$ tabel (o,361). Dengan hasil tersebut maka item 4 dan 5 dihapus dari instrumen variabel lingkungan kerja sehingga total pernyataan yang digunakan dalam variabel lingkungan kerja menjadi lima. Pada variabel kepuasan kerja didapati bahwa semua pernyataan memiliki nilai $r$ hitung $>\mathrm{r}$ tabel $(0,361)$. Dengan hasil tersebut maka semua pernyataan pada variabel kepuasan kerja dapat dikatan valid sehingga dapat digunakan untuk hasil penelitian.

\section{Uji Reliabilitas}

Nilai uji reliabilitas dari variabel motivasi mendapatkan nilai alpha sebesar 83,8\%. Untuk variabel lingkungan kerja, nilai alpha sebesar 63,5\%. Untuk variabel kepuasan kerja, nilai alpha adalah 68,9\%. Dari hasi tersebut, disimpulkan bahwa semua 
pernyataan yang digunakan dalam kuesioner dapat dikatan reliable karena nilai alpa > 0,60, sehingga semua pernyataan dapat digunakan untuk hasil penelitian.

Tabel 1. Karakteristik Respondend

\begin{tabular}{l|l|r|c}
\hline Keterangan & \multicolumn{1}{|c|}{ Kriteria } & $\begin{array}{c}\text { Jumlah } \\
\text { Responden }\end{array}$ & $\%$ \\
\hline Jenis & Pria & 5 & $16,67 \%$ \\
Kelamin & Wanita & 25 & $83,33 \%$ \\
\hline Usia & $21-30$ & 10 & $33,33 \%$ \\
& $31-40$ & 6 & $20 \%$ \\
& $41-50$ & 7 & $23,33 \%$ \\
& $51-60$ & 7 & $23,34 \%$ \\
Pendidikan & SMA/Sederajat & - & 0 \\
\hline Derakhir & D3 & 2 & $6,67 \%$ \\
& S1 & - & - \\
& S2 & 27 & $90 \%$ \\
& S3 & 1 & $3,33 \%$ \\
Bama & $<1$ & - & - \\
\hline & $1-5$ & 4 & $13,33 \%$ \\
& $6-10$ & 12 & $40 \%$ \\
& $11-15$ & 3 & $10 \%$ \\
& $16-20$ & 4 & $13,33 \%$ \\
& $>20$ & 3 & $10 \%$ \\
& & 4 & $13,34 \%$ \\
\hline
\end{tabular}

Sumber:diolah oleh penulis

Tabel 1 menunjukan bahwa 83,33\% dari responded adalah perempuan. Dari segi usia, kebanyakan responden berusia 21-30, yaitu 33,33\%. Dari segi pendidikan terakhir mayoritas responden merupakan lulusan $\mathrm{S} 1$, yaitu 90\%. Dari segi lama bekerja mayoritas guru sudah bekerja selama 1 sampai 5 tahun yaitu, 40\%. Data responden yang dikumpulkan sudah mewakili beberapa guru yang ada di Sekolah Advent Air Bersih Medan.

\section{Uji Analisis Koefisien Determinasi}

Tabel 2. Uji Analisis Koefisien Determinasi

\begin{tabular}{|c|c|c|c|c|}
\hline Model & $\mathbf{R}$ & $\begin{array}{l}\text { R } \\
\text { Square }\end{array}$ & $\begin{array}{l}\text { Adjusted } \\
\text { R } \\
\text { Square } \\
\end{array}$ & $\begin{array}{l}\text { Std.Error } \\
\text { of the } \\
\text { Estimate }\end{array}$ \\
\hline 1 & 684, & .467. & .428 & 1.99933 \\
\hline
\end{tabular}

\section{Hasil Analisis Koefisien}

Determinasi ditunjukkan dalam tabel 1, nilai koefisien determinasi ( $R$ Square) sebesar 0,467 atau sebesar $46,7 \%$ dimana dengan hasil ini dilihat bahwa variabel motivasi dan lingkungan kerja berpengaruh terhadap kepuasan kerja dan sisanya 53,3\% dipengaruhi oleh variabel lainnya yang tidak diteliti dalam penulisan ini. Dari hasil diatas nilai dari $\left(\mathrm{R}^{2}\right)$ sebesar o,684 dimana variabel $\mathrm{X}$ dan Y memiliki hubungan yang tetap.

\section{Analisis Uji Parsial}

\begin{tabular}{|c|c|c|c|c|c|}
\hline \multirow[t]{2}{*}{ Model } & \multicolumn{2}{|c|}{$\begin{array}{l}\text { Unstandardized } \\
\text { Cofficients }\end{array}$} & & \multirow[t]{2}{*}{$\mathrm{T}$} & \multirow[t]{2}{*}{ Sig } \\
\hline & B & $\begin{array}{l}\text { Std.Er } \\
\text { ror }\end{array}$ & $\mathrm{B}$ & & \\
\hline Constant & 5.811 & 3.914 & & 1.485 & .149 \\
\hline Motivasi & .282 & 0.77 & .583 & 3.668 & .001 \\
\hline $\begin{array}{c}\text { Lingkungan } \\
\text { Kerja }\end{array}$ & .121 & .109 & .177 & 1.112 & .276 \\
\hline
\end{tabular}

Dari tabel 3 diatas diketahui bahwa nilai signifikan antara variabel motivasi dengan kepuasan kerja adalah o,001 dan nilai thitung sebesar 3.668 > dari Ttabel yaitu 2,055 maka disimpulkan variabel motivasi memiliki pengaruh yang signifikan terhadap kepuasan kerja. Berikutnya, nilai dari thitung sebesar 1,112 $<$ dari ttabel 2,005 dapat disimpulakn variabel lingkungan kerja tidak berpengaruh signifikan terhadap kepuasan kerja.

\begin{tabular}{c|c|c|c|c|c}
\multicolumn{7}{c}{ Tabel 4. Uji Simultan } \\
\hline & $\begin{array}{c}\text { Sum of } \\
\text { Square }\end{array}$ & Df & $\begin{array}{c}\text { Mean } \\
\text { Square }\end{array}$ & F & Sig. \\
\hline Regression & 94.739 & 2 & 47.369 & 11.850 &. .000 $^{\mathrm{b}}$ \\
Residual & 107.928 & 27 & 3.997 & & \\
Total & 202.667 & 29 & & & \\
\hline
\end{tabular}

Sumber: Data Diolah oleh Peneliti 2021

Dari tabel 4 yang terdapat diatas dapat dilihat nilai dari fhitung sendiri sebesar 11,850, jadi untuk fhitung 11,850 > dari ftabel yaitu 2,98. Maka dapat disimpulkan bahwa variabel motivasi (X1) dan lingkungan kerja (X2) berpengaruh secara simultan terhadap kepuasan kerja (Y).Pembahasan

\section{Pembahasan}




\section{Pengaruh Motivasi dan Lingkungan Kerja Terhadap Keputusan Kerja}

Berdasarkan perhitungan yang dilakukan diatas diperoleh hasil uji $\mathrm{F}$ atau uji simultan sebesar o,ooo lebih kecil dari 0,05 dengan nilai $\mathrm{F}_{\text {tabel sebesar }}$ 3,35 .Hal tersebut membuktikan bahwa adanya pengaruh motivasi dan lingkugan kerja secara bersama-sama berpengaruh signifikan terhadap kepuasan kerja. Hasil penelitian ini juga didukung oleh penelitian terdahulu oleh Lumentut dan Dotulong (2015) yang meyatakan adanya pengaruh signifikan antara motivasi,disiplin kerja dan lingkungan kerja terhadap kepuasan kerja karyawan.

\section{Pengaruh Motivasi Terhadap Kepuasan Kerja}

Berdasarkan uji $\mathrm{t}$ yang telah dilakukan maka diperoleh nilai $\mathrm{t}$ dari motivasi kerja memiliki sebesar 0,443 dengan nilai signifikansi o,001 . Hasil ini menunjukkan bahwa motivasi berpengaruh positif dan signifikan terhadap Kepuasan Kerja Guru pada Sekolah Advent Air Bersih Medan di masa pandemi covid-19.

Pengecekan diatas mampu menerima hipotesis pertama, sehingga pernyataan yang menyatakan motivasi berpengaruh positif terhadap kepuasan kerja guru diterima. Pernyataan diatas didukung dengan penelitian Uno (2009) dan Kristiawan (2019) motivasi kerja guru adalah suatu tahapan yang dilakukan dalam menuntun guru agar sikap yang mereka berikan dapat diarahkan pada pelaksanaan yang nyata dalam mencapai tujuan yang telah ditetapkan. Dengan terbentuknya motivasi kerja guru maka akan meningkatkan kepuasan kerja. Dalam memotivasi banyak cara yang dapat dilakukan, seperti memberikan kepercayaan kepada guru untuk melakukan pekerjaan dengan tujuan yang baik.

Terhadap kinerja operasional karena total quality management terjaga dari segi kerjasama tim (team work). Karyawan melakukan pekerjaan dengan tanggung- jawab penuh, terjalinnya kerjasama yang solid didalam tim kerja., hubungan kerja antara karyawan dengan atasan terjalin baik. Hal tersebut sesuai hasil penelitian yang dilakukan oleh Wibowo, et al (2017) menghasilkan penelitiannya yaitu penerapan Dengan hasil penelitiannya yaitu total quality management berpengaruh secara signifikan pada kinerja operasional. Artinya dibutuhkan total quality management untuk membimbing dan mendorong manajemen dan seluruh karyawan mempunyai komitmen dan peran aktif untuk mencapai peningkatan kinerja di setiap level operasi dan mencapai kesempurnaan dalam setiap aspek produk yang penting bagi pelanggan.

\section{Pengaruh Lingkungan Kerja Terhadap Kepuasan Kerja}

Berdasarkan uji $\mathrm{t}$ yang telah dilakukan maka diperoleh nilai $\mathrm{t}$ dari motivasi kerja memiliki sebesar 0,202 dengan nilai signifikansi o,276. Hasil ini menunjukkan bahwa lingkungan kerja berpengaruh positif namun tidak signifikan terhadap kepuasan kerja guru. Dari hasil pernyataan diatas bisa dilihat bagaimana lingkungan kerja merupakan sarana yang sangat penting dalam melakukan pembelajaran. Karena dalam teori Utami (2014) lingkungan kerja merupakan suasana disekitar para guru dimana dapat memberikan pengaruh kepada individu dalam melaksanakan tugas-tugas atau tanggungjawab yang diberikan secara fisik maupun nonfisik. 
Dalam teori diatas bisa dikatakan lingkungan kerja sangat penting untuk para guru, namun saat pandemi covid-19 guru merasa mereka kurang mendapat pengaruh dalam lingkungan kerja yang saat ini.

\section{KESIMPULAN}

Berdasarkan hasil analisis dan pembahasan yang dilakukan, maka dapat disimpulkan sebagai berikut : bahwa motivasi sangat berpengaruh positif dan signifikan terhadap Kepuasan Kerja Guru di Sekolah Advent Air Bersih Medan pada masa pandemi Cvid-19. Dimana motivasi yang didapatkan dalam bentuk bagaimana sesama tenaga pengajar dan juga pemimpin mengakui akan apa yang telah dilakukan untuk dapat memajukan sekolah secara bersama-sama. Ketika Motivasi pada guru meningkat maka kepuasan kerja yang dirasakan akan meningkat. Meskipun pada masa Covid-19 guru-guru di Sekolah Advent Air Bersih Medan masih memiliki motivasi yang besar untuk memberikan yang terbaik bagi siswa didiknya.

Lingkungan kerja berpengaruh positif namun tidak berpengaruh signifikan terhadap Kepuasan Kerja Guru di Sekolah Advent Air Bersih Medan pada masa pandemi Covid-19. Mengartikan bahwa lingkungan kerja seorang tenaga pengajar pada saat Pandemi Covid-19 adalah baik, namun tidak ada kepuasan kerja pada tenaga pengajar. Dimana seorang tenaga pengajar tidak langsung bertatap muka dengan siswa-siswi. Tenaga pengajar akan merasa sulit untuk mengetahui pemahaman maupun kemampuan yang di miliki siswa-siswi. Dengan begitu sulit untuk tenaga pengajar mengetahui apakah tenaga pengajar puas akan kerja dan pengajaran yang dilakukan.

Secara simultan, jika digabungkan maka motivasi dan lingkungan kerja berpengaruh positif dan signifikan terhadap kepuasan kerja guru di sekolah advent air bersih medan di masa pandemi Covid-19.

\section{SARAN}

Peneliti memberikan saran kepada pimpinan Sekolah Advent Air Bersih untuk dapat meningkatkan kepuasan kerja guru-guru yang ada di sekolah tersebut, yaitu : 1) Hasi dari penelitian yang dilakukan bahwa motivasi memiliki hasil yang positif terhadap kepuasan kerja. dengan hasil ini peneliti memberikan saran agar pimpinan Sekolah Air Bersih mempertahankan atau menambahkan motivasi kepada guru yang mengajar pada Sekolah Advent Air Bersih, agar kepuasan kerja dari setiap guru dapat selalu meningkat. 2) Untuk saran dalam lingkungan kerja pada guru-guru Sekolah Advent Air Bersih supaya lebih kreatif dan inovatif dalam mengajar secara Online seperti sekarang ini, agar meningkatkan kepuasan kerja. 3) Sebagai saran teoritis, peneliti memberikan saran kepada peneliti selanjutnya untuk menggunakan faktor-faktor lain yang akan mempengaruhi kepuasan kerja. Faktorfaktor lain yang dapat digunakan seperti faktor stres kerja, komonikasi, kepemimpinan, beban kerja. Penulis berharap dengan faktor-faktor tersebut, dapat memberikan hasil yang lebih baik lagi.

\section{DAFTAR PUSTAKA}

Abdulahi, B. A. (2020). Determinants of Teachers' Job Satisfaction: School Culture Perspective. Jurnal

Humaniora, 32(2), 151. 
Al Atiyah, R., Isjoni, I., \& Sumardi, S. Pengaruh Kompensasi Dan Lingkungan Kerja Terhadap Kepuasan Kerja Guru Smp Negeri Negeri Di Kecamatan Kampar Kabupaten Kampar. Jurnal JUMPED (Jurnal Manajemen Pendidikan), 5(2), 315-323.

Amin, M. (2015). Relationship between job satisfaction, working conditions, motivation of teachers to teach and job performance of teachers in MTs, serang, banten.J. Mgmt. \& Sustainability, 5, 141.

Arisanti, K. D., Santoso, A., \& Wahyuni, S. (2019). Pengaruh Motivasi Kerja Dan Disiplin Kerja Terhadap Kinerja Karyawan Pada PT Pegadaian (Persero) Cabang Nganjuk. JIMEK: Jurnal Ilmiah Mahasiswa Ekonomi, 2(1), 101-118.

Danish, R. Q., \& Usman, A. (2010). Impact of reward and recognition on job satisfaction and motivation: An empirical study from Pakistan. International journal of business and management,5(2), 159.

Darmawan, D. (2016). Peranan Motivasi Kerja, Komitmen Organisasi dan Budaya Organisasi terhadap Kepuasan Kerja.Jurnal Ilmiah Manajemen Pendidikan Indonesia, 2(3), 109-118.

Filgona, J., Sakiyo, J., Gwany, D. M., \& Okoronka, A. U. (2020). Motivation in Learning. Asian Journal of Education and Social Studies, 1637.

https://doi.org/10.9734/ajess/2020 /v10i430273

Firmansyah, F. (2008). Pengaruh Lingkungan Kerja, Kompensasi, dan Kepemimpinan terhadap
Kepuasan Kerja Guru dan Karyawan di SMA Wachid Hasyim Surabaya. TADRIS: Jurnal Pendidikan Islam, 3(1).

Geby Citra Ananda. (2018). Pengaruh Lingkungan Kerja, Kepuasan Kerja, dan Stres Kerja Terhadap Komitmen Organisasi Guru TK dan SD pada Sekolah X di Jakarta Barat. Jurnal Manajemen Indonesia, 18(2), 154-164.

Gunaseelan, R., \& Ollukkaran, B. A. (2012). A study on the impact of work environment on employee performance. Namex International Journal of Management Research, 71, 1-16.

Hamdi, H., Asrin, A., \& Fahruddin, F. (2021). Kepuasan Kerja Guru SD pada Masa Pandemi Covid-19 di Gugus 2 Kecamatan Pemenang Lombok Utara Provinsi NTB. Jurnal Studi Guru dan Pembelajaran, 4(1), 157-162.

Hardiansyah, A., Soehardi, S., \& Rony, Z. T. (2019). PENGARUH DISIPLIN KERJA, MOTIVASI KERJA DAN KOMPENSASI TERHADAP KINERJA PEGAWAI BANK OCBC NISP BAGIAN RECORD MANAGEMENT DAN PARTNERSHIP OPERATION. Jurnal Ilmiah Manajemen Ubhara, 1(2), 147-161. https://doi.org/http://dx.doi.org/1 0.31599/jmu.v1i2.644

Hartoyo Darmawan, Soehardi Soehardi, \& Widjaja, A. W. (2019). PENGARUH BUDAYA ORGANISASI DAN MOTIVASI TERHADAP KINERJA ORGANISASI PEJABAT PENGELOLA INFORMASI DAN DOKUMENTASI (PPID) PERPUSTAKAAN NASIONAL RI. Jurnal Ilmiah Manajemen Ubhara, 
$1(2)$

$134-146$.

https://doi.org/http://dx.doi.org/1

0.31599/jmu.v1i2.646

Hermansyah, A. K., Sumarsono, A., Rahayu, D. P., \& Fredy, F. (2020). Motivasi Tenaga Pengajar Di Pedalaman Papua Dalam Mengajar dan Melanjutkan Studi pada Jurusan Pendidikan Guru Sekolah Dasar (Sebuah Kajian Fenomenologis). Sekolah Dasar: Kajian Teori dan Praktik Pendidikan, 29(1), 51-63.

Heryanto, H. (2019). The Effect of Work Motivation and Work Environment on Performance With Satisfaction as Intervening Variables Education Personnel Rektorate Andalas University. Archives of Business Research, 7(2).

https://www.kemdikbud.go.id/main/bl og/2020/05/kemendikbudterbitkan-pedomanpenyelenggaraan-belajar-darirumah

Iskandar, S., \& Juhana, E. (2014). Pengaruh Kompetensi Dan Lingkungan Kerja Terhadap Kepuasan Kerja Serta Implikasinya Pada Kinerja Guru Di SDN Baros Mandiri 5 Kota Cimahi. Jurnal Ekonomi, Bisnis \& Entrepreneurship, 8(2), 86-98.

Kalyar, M. N., Ahmad, B., \& Kalyar, H. (2018). Does teacher motivation lead to student motivation? The mediating role of teaching behavior. Voprosy Obrazovaniya, (3), 91-119. https://doi.org/10.17323/18149545-2018-3-91-119

Kartini, D., \& Kristiawan, M. (2019). Pengaruh tunjangan profesi dan motivasi kerja terhadap kinerja guru. Kelola: Jurnal Manajemen Pendidikan, 6(1), 25-33.

Khair, H. (2019). Pengaruh Kepemimpinan Dan Kompensasi Terhadap Kepuasan Kerja Melalui Motivasi Kerja. Maneggio: Jurnal Ilmiah Magister Manajemen, 2(1), 69-88.

Kristanti, E. (2017). Pengaruh Lingkungan Kerja Fisik dan Lingkungan Kerja Non Fisik terhadap Stres Kerja dan Dampaknya Terhadap Kinerja (Studi Pada Kantor Bersama Samsat Mojokerto Kota). Jurnal Ilmu Manajemen (JIM), 5(1).

Lumentut, M. D., \& Dotulong, L. O. (2015). Pengaruh motivasi, disiplin, dan lingkungan kerja terhadap kepuasan kerja karyawan pada PT. Bank Sulut Cabang Airmadidi. Jurnal EMBA: Jurnal Riset Ekonomi, Manajemen, Bisnis dan Akuntansi, 3(1).

Musanna, A. (2012). Quo Vadis Praksis Evaluasi Kurikulum: Studi Pendahuluan terhadap Ranah Kurikulum yang Terlupakan*.Jurnal Pendidikan dan Kebudayaan, 18(1), 1-11.

Novyanti, J. S. (2015). Pengaruh Motivasi Kerja, Lingkungan Kerja dan Disiplin Kerja terhadap Kinerja Pegawai pada BAPPEDA Provinsi Sulawesi Tengah. Katalogis, 3(1).

Purnamasari, D. (2018). Pengaruh Lingkungan Kerja Dan Disiplin Kerja Terhadap Kepuasan Kerja Guru Sekolah Menengah Kejuruan (Smk) Swasta Sekecamatan Pondok Aren.Jurnal Saintika Unpam: 
Jurnal Sains dan Matematika Unpam, 1(1), 108-132.

Rasyid, M. A. (2020). Pengaruh Kompensasi, Lingkungan Kerja dan Motivasi Terhadap Kepuasan Kerja Guru pada SMA Swasta Perkumpulan Amal Bakti 4 Sampali Medan. Maneggio: Jurnal Ilmiah Magister Manajemen, 3(1), 60-74.

https://doi.org/10.30596/maneg gio.v3i1.4698.

Rosowulan, R. A. (2019). Pengaruh Lingkungan Kerja Dan Locus Of Control Terhadap Kepuasan Kerja Guru Honorer Smk Negeri Di Kota Bekasi. Bionatural: Jurnal Ilmiah Pendidikan Biologi, 5(1).

Ruscahyono, H. (2014). Pengaruh Locus of Control dan lingkungan kerja terhadap kinerja guru SMKN 4 Klaten dengan kepuasan kerja sebagai intervening. AKTUAL, 1(2).

Sari, F. M. (2013). Pengaruh kompetensi dan lingkungan kerja terhadap kepuasan kerja dan kinerja guru di SD Negeri Kecamatan Gondang Mojokerto. Die, 9(2).

Seniwoliba, J. A. (2013). Teacher motivation and job satisfaction in senior high schools in the Tamale metropolis of Ghana.

Tetuko, B. (2012). Pengaruh Motivasi Kerja, Budaya Organisasi, Kepemimpinan Kepala Sekolah Terhadap Kepuasan Kerja dan Kinerja Guru SMA Swasta di Kabupaten Grobogan. Educational Management, 1(2).
Toropova, A., Myrberg, E., \& Johansson, S. (2021). Teacher job satisfaction: the importance of school working conditions and teacher characteristics. Educational

Review, 73(1), 71-97. https://doi.org/10.108o/o013191 1.2019.1705247

Utami, R. S., \& Tarmudji, T. (2014). Pengaruh Lingkungan Kerja Dan Kompensasi Kerja Melalui Motivasi Kerja Sebagai Variabel Intervening Terhadap Kinerja Guru Di SMA Negeri 7 Semarang Pada Tahun 2013/2014. Economic Education Analysis Journal, 3(2).

Wibowo, M. (2014). Pengaruh lingkungan kerja terhadap kepuasan kerja karyawan (Studi pada karyawan PT. Telekomunikasi Indonesia Tbk. Kandatel Malang). Jurnal Administrasi Bisnis, 16(1)

Yumaroh, M., \& Andriani, L. (2017). Pengaruh lingkungan kerja terhadap kinerja guru di SMK Negeri 10 Kecamatan Sungai Gelam Kabupaten Muaro Jambi. SJEE: Scientific Journals of Economic Education, 1(1), 7684. 
108 | Jurnal Ilmiah Manajemen Ubhara, Volume 3, No 2, Oktober 2021. ISSN 1858 -1358, E - ISSN 2684 - 7000 